Open Access

\title{
Performance and capital structure of IPOs in Pakistan from 2000 to 2015
}

\author{
Attiya Yasmin Javid ${ }^{1 *}$ and Henna Malik²
}

\author{
* Correspondence: \\ attiyajavid@pide.org.pk \\ ${ }^{1}$ Economics Department, Pakistan \\ Institute of Development \\ Economics (PIDE), Quaid-i-Azam \\ University, P.O. Box 1091, Islamabad, \\ Pakistan \\ Full list of author information is \\ available at the end of the article
}

\begin{abstract}
Background: When a privately owned firm or privatized government entity raises capital by selling its stocks for the first time to general public, is known as initial public offering (IPO). The underpricing phenomenon and ownership structure are important characteristics of IPO process that significantly affect the short-run and long-run performance of private firm and privitized entity. This study compares the short-and long-run performance, and factors affecting these performances for both private IPOs and privatized IPOs in Pakistan. It further investigates the relationship between capital structor and initial underpricing for both group of IPOs.
\end{abstract}

Methods: Event study methodology is used to compares short- and long-run performance spanning from March 2000 to June 2015 of two categories of IPOs issued in the Karachi Stock Exchange (KSE). Multivariate regression analysis is applied to examine the factors that affect the short-run and long-run performance as well as for investigating the relationship betwen underpricing and ownership structure for both group of IPOs.

Results: We find that both categories outperform in IPOs at which they are offered to investors on first day of trading, although differences in mean are insignificant. Over a five-year buy-and hold strategy, privatizing IPOs outperform and private IPOs underperform returns on the benchmark KSE 100 Stock Index. The results reveal that the size of the private firm or government entity, aftermarket risk of IPOs, and subscription ratio are significantly associated with the underpricing of IPO shares brought to market. First-day returns, market volatility and retained ownership are associated with higher five-year performance. We find that the concentration of ownership is similar, for both categories of IPOs; and significantly positive related to underpricing. The size of the firm/entity, aftermarket risk, return on assets and subscription ratio also affect ownership concentration.

Conclusions: Same level of underpricing in both private and privatized IPOs reveals that Pakistan's government is committed to its privatization policies as they developed capital markets by underpricing of IPOs. To make dispersion in ownership structure and to involve more small investors, the regulatory authorities such as Securities and Exchange Commission of Pakistan (SECP are required to take some steps to minimize concentration in ownership structure. There is a need of some specific range of underpricing by issuers and SECP.

Keywords: Initial public offering, Underpricing, Aftermarket performance, Private owned firms, Public owned firms, Capital structure, Pakistan

JEL Classification: G14, G24, G32 


\section{Background}

An initial public offering (IPO) is a mechanism by which a privately owned company sells its common shares to the general public for the first time. IPOs are also the mechanism by which governments privatize public sector entities (i.e., transfer their ownership and control to the private sector, where they are managed as commercial activities). Shares sold via IPOs enter trading on public equity markets (Barnes and Walker 2006). On the day that they are issued, shares offered via IPOs generally close at prices exceeding the price at which they were offered to investors. Thus, some studies argue that IPO shares generally are underpriced (Aggarwal, 1993; Loughran and Ritter 2000). However, empirical evidence from developed markets indicates that long-run performance of IPO shares tied to the performance of broader markets (Levis 1993; Aggarwal et al. 1993).

Numerous studies examine initial and aftermarket performance of IPO shares in developed countries, but few address emerging markets. Even fewer explicitly compare price behaviors of IPOs involving privately owned firms and those that involve privatizing public sector entities. Vickers and Yarrow (1988), Jenkinson and Mayer (1988), Jacquillat (1987), and Perotti and Guney (1993) suggest that underpricing is greater among IPOs for privatized public entities than it is among IPOs for privately owned firms. Empirical evidence also suggests that share prices for private enterprises underperform during their initial three-to-five years of aftermarket trading, whereas privatized public.entities generally outperform in long-run trading. ${ }^{1}$ However, those results pertain to developed markets and may differ in emerging capital markets. The only Pakistani study is by Rizwan and Khan (2007), who compared the short- and long-run performance of IPOs of publicly owned enterprises and privately owned firms by sampling 35 offerings from 2000-2006. The paucity of scholarship motivates this study.

This study measures, analyzes, and compares the short- and long-run performance of IPOs. We define "short-run performance" as the price behavior on the first day that an IPO trades and "long-run performance" as the price behavior spanning five years following an IPO. It examines IPOs for both privately owned firms (private IPOs) and public entities (privatizing IPOs) listed on Pakistan's Karachi Stock Exchange (KSE). It examines the factors that affect initial underpricing on the first day of trading and aftermarket performance for both groups of IPOs.

We further investigate the relationship between ownership structure and initial underpricing of private and privatized IPOs. When "going public," firms may seek to concentrate ownership to sequester gains among their owners and reduce agency cost, or they might wish to disperse ownership to enhance aftermarket liquidity. The ownership structure is pivotal to corporate finance in emerging markets (LaPorta et al., 1999).

We extend the literature by investigating two anomalies: the short-run outperformance and long-run underperformance of private and privatizing IPOs in Pakistan. We also compare the ownership structure and underpricing of both categories of IPOs. No previous research addresses either subject in Pakistan.

Our results indicate that private and privatizing IPOs outperform on their first trading day. In the long run, private IPOs underperform and privatizing IPOs outperform although the mean difference between them is insignificant in the short and long runs. The size of the firm, aftermarket risk, and subscription ratio significantly influence underpricing. First-day returns, market volatility, and retained ownership determine the 
IPOs' performance over five years. Ownership concentration in both categories is similar. The extent of underpricing, firm size, aftermarket risk, return on assets, and subscription ratio affect the concentration of ownership.

This study proceeds as follows. Section 2 reviews IPOs in Pakistan. Section 3 presents an empirical review, theoretical background, and hypothesis development. Section 4 discusses the method, variables, and data sources. Section 5 presents the empirical results. Section 6 concludes the paper and discusses policy implications.

\section{Overview of ipos in Pakistan}

IPOs are not new in Pakistani capital markets. On April 2, 1949, Karachi Electric Supply Corporation became the first company to list on the KSE, ${ }^{2}$ albeit without a prospectus. In 1953, M/s Hussain Industries launched the practice of issuing a prospectus to encourage subscriptions from the public. Political instability and nationalization impeded the issuance of IPOs from 1953 to 1990. Reforms in 1991 strengthened capital markets. Thereafter private firms issued IPOs to diversify ownership and financing, and their numbers rose substantially from 1991 to 1996 . The Pakistani government also began to privatize public entities to encourage domestic and international investment through enhanced efficiency and transparency. During the next decade, privatization gathered momentum, although generally without improving transparency or operating performance, and slowed from 2008 to 2013. Pakistan's present government has revived privatization with the intent improving on those objectives. Initially, Pakistani IPOs came to market only under a fixed-price offer method. Equity markets required more efficient and investor-friendly mechanisms, and the book-building method was introduced in March 2008. Few private investors participate in Pakistani stock markets. Business ownership is concentrated among family members, and it might be less costly for firms to issue debt than equity. From liberalization in 1992 until 1999, the KSE averaged 35 IPOs yearly. The number dwindled to an average of seven yearly. This decrease may be attributable to social, political, and security issues such as the sanctions imposed in 1998 after Pakistan conducted nuclear tests. There was one IPO in 1998 and none in 1999. Pakistani stock market activity diminished after 9/11 until 2003. Trading increased from 2004 until the 2007-2008 global financial crisis. Overall only ninety IPOs came to market from 1999 to March 2015.

\section{Literature review}

This section reviews earlier studies of IPO underpricing, long-run performance and ownership structure.

\section{Empirical literature}

On average, investors briefly earn positive abnormal returns from an IPO, a phenomenon known as initial underpricing. Ibbotson (1975) reported that IPOs are underpriced 11.4\% by comparing issue prices with prices after one month of trading. Document initial underpricing of $16.8 \%$ using a larger sample. Other studies that confirm initial underpricing include Ritter (1984), Miller and Reilly (1987), Tinic (1988), Beatty (1986), Carter and Manaster (1990), and Ibbotson, Sindelar, and Ritter (1988).

Initial underpricing phenomenon is not confined to the US. Aggarwal, Leal, and Hernandez (1993) report initial underpricing of $78.5 \%$ in Brazil in a sample of 62 offerings 
from 1980-1990, 16.3\% in Chile (36 IPOs from 1982-1990), and 33.0\% in Mexico (44 IPOs from 1987-1990).

Evidence indicates underpricing among IPOs of privatized public entities. Jenkinson and Mayer (1988) show they are underpriced an average 25.1\% in France and 22.2\% in the UK. Perotti and Guney (1993) find that IPOs of privatize public enterprises are underpriced in Turkey, Malaysia, and Spain. They suggest there are strong regularities in privatization programs in these countries. Governments generally retain substantial stakes in privatized public entities and offer only partial ownership through IPOs.

Studies that compare privatizing IPOs with private IPOs present contradictory evidence (Choi and Nam 1998; Vieira and Serra 2006; Breda et al. 1997). Menyah and Paudyal (1996) document that privatizing IPOs generate significant positive initial marketadjusted returns compared to private IPOs in the UK. In their eight-country sample, Dewenter and Malatesta (1997) find evidence that only in the UK, privatizing IPOs are more underpriced than private IPOs (Malaysia, Canada, Japan, France, Poland, Thailand, Hungary, and the UK). In contrast, Paudyal et al. (1998) find that initial underpricing of privatizing IPOs significantly exceeds underpricing of private IPOs in Malaysia.

Jelic and Briston (1999) confirm those results for Hungary, as do Setiobudi et al. (2011) for Indonesia and Aussenegg (2000) for Poland. Aussenegg (2000) argues that Poland's market-oriented government (Perotti, 1995) tries to elevate its reputation as a privatizer by offering high initial returns.

Another anomaly of IPOs is their poor long-run price performance. Ritter (1991) first documented this phenomenon, finding that US IPOs generated average three-year holding period returns of 34.37\%. Using Ritter's sample, Yi (1992) finds that Ritter's results extend six years after going public. Loughran and Ritter (1995) use a larger sample of IPOs and find poor stock performance extending five years after issue, with no further underperformance in the sixth year.

International comparisons of long-run performance for private and privatizing IPOs yield mixed evidence. Ritter (1991), Loughran and Ritter (1995), Levis (1993), and Keloharju (1993) show that private IPOs generally underperform three to five years in aftermarket trading. Other studies indicate that privatizing IPOs outperform private IPOs in the longrun. See Menyah and Paudyal (1996) for the UK, Jelic and Briston (1999) for Hungary, Ikoku (1998) for Nigeria, and Portugal. However, Paudyal et al. (1998) document no abnormal difference in long-run performance between privatizing and private IPOs for Malaysia, as do Aussenegg (2000) for Poland and Rizwan and Khan (2007) for Pakistan.

Earlier research employs assorted explanatory variables to examine long-run aftermarket performance. Cai, Liu, and Mase (2008) find that Chinese IPOs market are influenced by offer size, underpricing, oversubscription, and earnings growth. Chen et al. (2011) argue that long-run underperformance supports the signaling hypothesis and the ex-ante uncertainty hypothesis but not the divergence of opinion hypothesis. They conclude that earnings per share, offer size, aftermarket risk, and seasoned equity offerings impacting Chinese IPOs.

Lemmon and Lins (2003) and La Porta et al. (1999) consider whether ownership structure reduces agency problems between insiders and outsiders that may affect firms' valuations. Empirical results from examining IPO underpricing are ambiguous. Pham et al. (2003) find a negative association between shareholdings of the top 20 investors in Australian IPOs. Shehryar and Javid (2014) for Pakistan and Chen and 
Strange (2004) for China find a negative relation between ownership concentration and underpricing, supporting the ownership dispersion hypothesis. In contrast, Venkatesh and Neupane (2005) find no significant association between ownership concentration and underpricing among Thai IPOs.

Only one study compares private and privatizing IPOs in Pakistan. Rizwan and Khan (2007) examine 2000-2006 and find that initial market-adjusted returns of private and privatizing IPOs are significantly underpriced, but the mean differences are not statistically significant. They also report that firm size and the percentage of outstanding shares offered during an IPO significantly affect underpricing.

In sum, the literature suggests that considerable work remains in comparing results and anomalies among private and privatizing IPOs, especially in emerging markets like Pakistan.

\section{Theoretical literature and hypothesis development}

Several models provide theoretical frameworks for studying short-run and long-run performance of IPOs. Asymmetric information and the winner's curse hypothesis (Rock 1986) assert information asymmetry between informed and uninformed investors.

Informed investors subscribe to IPOs only when they expect positive initial returns, whereas uninformed investors subscribe promiscuously to IPOs. Given that issuers must attract uninformed and informed investors, they generally must underprice their issues to provide uninformed investors acceptable rates of return.

Rock's (1986) model describes underpricing as an ongoing search for equilibrium. However, that situation creates adverse selection problems when IPOs are underpriced. Given that the quantities awarded are rationed between uninformed and informed investors, offerings are over-subscribed by substantial multiples. That assures a positive relationship between underpricing and oversubscription. Koh and Walter (1989) and Michaely and Shaw (1994) confirm the implications of Rock's model.

It is argued that private IPOs generally involve large and well-known firms and that governments try to make abundant information available prior to IPOs wherein they privatize public entities. These efforts might create information asymmetry in both private and privatizing IPOs. We propose Hypothesis 1 :

Hypothesis 1: The means of initial market-adjusted returns from IPOs that privatize public entities are lower than for IPOs that involve privately owned firms.

Theories of asymmetric information argue that uncertainty over the value of recently established firms (i.e., new issues) exceeds uncertainty surrounding well-known firms. As a result, investors worry more about their future, post-IPO performance. There may be a positive relation between underpricing and such ex-ante uncertainty Beatty and Ritter (1986).

Signaling models (Allen and Faulhaber 1989; Welch 1989; Grinblatt and Hwang 1989) hold that issuers might have better information about a firm's value than outsiders. Therefore, high value firms may underprice their IPOs and retain insider ownership to signal their superior quality. Thereafter, owner/managers can price subsequent offerings higher or enjoy greater gains on the equity they retain. If so, there is a positive relationship between initial market-adjusted returns and ratio of shares retained by insiders. However, the relationship between underpricing and retained ownership is negative for IPOs that privatize public sector entities. ${ }^{3}$ 
A successful IPOs in one in which the market price on the first day of trading does not fall below the issue price. Documents that if market volatility is high, regulators try to minimize the probability of unsuccessful issues by lowering prices, which amplifies underpricing. Thus the relation between underpricing and the market volatility is positive.

Divergence of opinion theory suggests IPOs attract investors who are most optimistic about the issue. As a practical matter, market prices are set by this group rather by investors overall. Further, the greater the uncertainty about the value of an IPO, the more optimistic investors will pay relative to other investors. In the long-run, more information about the issuer becomes available, and divergence of opinion between groups of investors narrows. Consequently, market price falls. Miller (1977) predicts that IPOs, especially riskier issues, underperform in the long run.

Hypothesis 2: Long-run price performance of IPOs that privatize public entities significantly exceeds that of IPOs involving privately held firms.

Positive long-run performance by privatizing IPOs serves the objectives market oriented governments. Privatization programs generally last several years, and committed governments want to build a sustained reputation for supporting privatization. We test the following hypothesis for Pakistan:

Hypothesis 3: Five-year aftermarket performance of privatizing IPOs is nonnegative.

Boycko et al. (1996) show that the ratio of shares governments retain during IPOs is important for maintaining the credibility of restructuring public enterprises. If lower state ownership portends more efficient restructuring, the long-run performance of IPO shares may be positive.

Investor sentiment theory argues that overly optimistic investors over value IPO prices in the short-run, which erodes long-run performance (Aggarwal and Rivoli, 1990); Ritter (1991); Loughran and Ritter (1995). Privately owned firms consider investors' over-optimism when timing IPOs. If investors shed their optimism over time, long-run performance erodes (investor sentiment hypothesis). We use the subscription ratio as a proxy for investor optimism and expect to find negative relations between subscription ratio and long-run performance.

Signaling theory suggests that issuers use the retention ratio to broadcast the quality of an IPO. A high retention ratio indicates higher quality by implying that owners are reluctant to relinquish promising cash flows. Jenkinson and Mayer (1988) and Menyah and Paudyal (1996) show that underpricing of privatizing IPOs in the UK exceeds underpricing of IPOs involving privately held firms and that governments retain large stakes in privatized entities long after transferring ownership to the private sector.

Hypothesis 4: The relation between ownership structure and underpricing is higher for privatizing IPOs than for private IPOs.

\section{Method and data}

\section{Determinants of IPOs underpricing in public and private owned firms}

We examine determinants of underpricing for privatizing and private IPOs through multivariate cross-sectional analysis of the first day of trading. A dummy variable with 
market-adjusted returns to compare the two categories of IPOs takes the value 1 for privatizing IPOs and 0 otherwise, following Setiobudi et al. (2011). We use OLS regression to estimate this model $^{4}$ :

$$
\begin{aligned}
\text { MAR }_{i}= & \beta_{0}+\beta_{1} \text { Pub }_{i}+\beta_{2} M_{-} \text {Volt }_{i}+\beta_{3} \text { F_Size }_{i}+\beta_{4} \text { Subs }_{i}+\beta_{5} \text { Ret_own }_{i} \\
& +\beta_{6} \text { Risk }_{i}+\beta_{7} I \text { Proceed }_{i}+\varepsilon_{i}
\end{aligned}
$$

In Eq. 4.1, $M A R_{i}$ is market-adjusted abnormal returns of issue $\mathrm{i}$ on the first day of trading. $P u b_{i}$ is a dummy taking the value of 1 if the IPO involves a government entity and 0 otherwise. $M_{-}$Volt $_{i}$ denotes market volatility over two months prior to issue i. $F_{-}$Size $_{i}$ is firm size of issue $\mathrm{i}$, which includes the size of both group of firms. Subs $s_{i}$ is subscription ratio of issue i. Ret_own $n_{i}$ is retained ownership by public and private firms of issue i. ${ }^{5}$ Risk $_{i}$ is aftermarket risk of public entities and privately owned firms. I_Proceeds $s_{i}$ denotes revenues received from the issue i. The $\beta s$ are parameters to estimate. $\varepsilon_{\mathrm{i}}$ is the error term.

\section{Determinants of long-run performance of private and privatizing IPOs}

We investigate determinants of long-run abnormal returns those exceeding a benchmark index for privately owned firms and public entities using the same model (4.1) with an additional variable for market-adjusted abnormal returns on the first day.

$$
\begin{aligned}
\text { BHAR }_{i}= & \beta_{0}+\beta_{1} \text { MAR }_{i}+\beta_{2} \text { Pub }_{i}+\beta_{3} \text { MVolt } \\
& +\beta_{4} \text { FSize }_{i}+\beta_{5} \text { Subs }_{i} \\
& +\beta_{6} \text { Retown }_{i}+\beta_{7} \text { Risk }_{i}+\beta_{8} \text { IProceed }_{i}+\varepsilon_{i}
\end{aligned}
$$

$B H A R_{i}$ is aftermarket long-run abnormal returns of issue i over five years.

\section{Ownership structure and underpricing}

We follow the methodology of Pham et al. (2003) to compare the relationship between underpricing and ownership structure for both categories of IPOs. We use characteristics of private firms and public entities such as subscription ratio, return on assets, size, and risk as factors that influence ownership structure. The following cross-section model is estimated by OLS:

$$
\text { Ownership }_{i}=\beta_{0}+\beta_{1} \text { Pub }_{i}+\beta_{2} M A R_{i}+\beta_{3} F_{S} i z e_{i}+\beta_{4} \text { Subs }_{i}+\beta_{5} R O A_{i}+\beta_{6} \text { Risk }_{i}+\varepsilon_{i}
$$

All independent variables remain the same as in Model (4.1). We measure concentration and unbalanced ownership structure using the $H H I$ and proportions of shares owned by holders of large blocks (BLOCK).

\section{Definition and construction of variables}

\section{Measure of initial returns}

We analyzed initial returns using daily market-adjusted returns calculated by traditional event study methodology (Suchard and Singh, 2007).

We measured initial market-adjusted abnormal returns for the first day of trading as the difference between initial raw returns and the raw return for the KS-100 index for both categories of IPOs. Returns are dividend adjusted. To calculate initial abnormal returns, we adjusted the raw returns with the returns of market index so as to remove the effect of general movements in share prices Dewenter and Malatesta (1997). 


$$
M A R_{i, t}=\ln \left(\frac{P_{i, t}}{P_{i, t-1}}\right)-\ln \left(\frac{I_{i, t}}{I_{i, t-1}}\right)
$$

$M A R_{i}$ is market-adjusted abnormal returns of stock $\mathrm{i}$ on day t. $P_{i, t}$ and $P_{i, t-1}$ represent adjusted closing prices on days $\mathrm{t}$ and $\mathrm{t}-1 . I_{i, t}$ and $I_{i, t-1}$ are closing values of the market index on the corresponding ith issue on days $\mathrm{t}$ and $\mathrm{t}-1$. To test the null hypothesis that the mean $M A R_{i}$ of private IPOs equals that for privatizing IPOs, we use $p$ values per Setiobudi et al. (2011).

\section{Measure of aftermarket performance}

To measure aftermarket performance of IPOs, we first calculate buy-and-hold returns for each issue using event study methodology. ${ }^{6}$ Price performance measured as buyand-hold returns has the advantage over cumulative returns of being based on a realistic ex-ante trading strategy. We use compounded abnormal returns over a specific period as given below:

$$
\operatorname{BHAR}_{i, T}=\left[\prod_{t=1}^{T}\left(1+R_{i, t}\right)\right]-1
$$

$R_{i, t}$ is the return of IPO $i$ in period t. $\mathrm{t}=1$ indicates the first day of aftermarket trading. ${ }^{7}$ BHARs are calculated for $\mathrm{T}=1$ week, 2 weeks, 1 month, 2 months, 3 months and 6 months, 1 year, 2 years, 3 years, 4 years, and five years.

Aftermarket performance is measured against the KSE-100 Index as a benchmark value-weighted index. The BHR of the KSE-100 Index to the corresponding of $I P O_{i}$ $\left(B H R_{K S E, i, t}\right)$ is calculated in the manner portrayed in Eq. (4.6). For each corresponding IPO, the product of all previous returns of the KSE-100 are calculated up to their specified time periods as given above.

Use of market indices as benchmarks is common in the literature. ${ }^{8}$ This measure is suitable for investigating short-run aftermarket performance Kooli and Suret (2004), especially in Pakistani capital markets, where lengthy time gaps are more persistent than in developed markets. We measure short-run aftermarket-adjusted abnormal returns on the first trading day and long-run aftermarket market-adjusted returns over five years for both categories of IPOs.

As Ritter (1991) and Barber and Lyon (1997) suggest, we measure abnormal buyand-hold returns for each IPO and its benchmark (KSE-100 Index). ${ }^{9}$

$$
\text { BHAR }_{t}=\left[\prod_{t=1}^{T}\left(1+R_{i, t}\right)-1\right]-\left[\prod_{t=1}^{T}\left(1+R_{K S E, i, t}\right)-1\right]
$$

Average $B H A R_{T}$ is defined as:

$$
B H A R_{T}=\frac{1}{n} \sum_{i=0}^{n} B H A R_{i, t}
$$

In Eq. 4.8, $\mathrm{n}$ is the number of IPOs sampled. Following Lyon, Barber, and Tsai (1999), we use skewness-adjusted bootstrapped $p$-values to test the null hypothesis that the mean BHARs of private and privatizing IPOs are similar. 
Following Ritter (1991), we measure wealth relatives (WRs) to compare the performance of an IPO against the benchmark. ${ }^{10}$ Values exceeding (below) 1 mean an IPO outperforms (underperforms) its benchmark. WR is calculated as:

$$
W R_{T}=\frac{1+\text { Average } B H R_{i, t}}{1+\text { Average } B H R_{K S E, t}}
$$

$W R_{T}$ is wealth relative over period T. Average $B H R_{i, t}$ is average abnormal buy-andhold return of issue i over period t. Average $B H R_{K S E, t}$ is average buy-and-hold return for the reference portfolio over period $\mathrm{T}$.

\section{Measures of ownership structure}

Ownership of quality firms is concentrated among investors who hold large blocks of stock. Most Pakistani firms are owned by the families or institutions (Cheema et al. 2003). Therefore as a proxy for unbalanced ownership we use block holdings i.e., investors who own more than 5\% of issued equity. We calculate this proxy below per Brennan and Franks (1997) and Stoughton and Zechner (1998):

$$
\text { BLOCK }=\left(\sum_{k=1}^{m} \text { Block Size-Retain }\right) / \text { Offer Size }
$$

To measure concentration of ownership structure, we calculate HerfindhalHirschmann Index $(H H I)$ :

$$
H H I=\sum_{i=1}^{5} S^{2} i
$$

Here, $S_{i}$ belongs to the $i^{\text {th }}$ largest shareholder $(i=1,2,3,4,5)$. HHI spans from nearly 0 to 10,000 , as close. Proximity to $0(10,000)$ means low (high) concentration. To deal with possible normality in the $\mathrm{HHI}$, we replaced the original value of the index with its square root (Pham et al., 2003).

\section{Description of other variables}

Firm Size: Size may indicate firm's quality or reduced information uncertainty. It is measured as the natural log of total assets of issuing firms, at the end of 12-month period nearest the time of listing (Suchard and Singh, 2007).

Issue Proceeds: Issue proceeds are measured by the natural log of market capitalization after IPO shares begin trading. Market capitalization is calculated by multiplying the number of shares issued by their offer price.

Subscription Ratio: The subscription ratio is the number of IPO shares buyers wish to purchase divided by the number offered (Al-Hassan et al. 2010; Habib and Ljungqvist 2001).

Retained Ownership Ratio: The number of shares retained by the issuer as a percentage of total shares issued.

Risk: Standard deviation of daily share returns during the first month of aftermarket trading (Demsetz and Lehn 1985; Leech and Leahy 1991). The level of risk affects underpricing. 
Market Volatility: Standard deviation of daily share returns of the KSE-100 Index for two months prior to an IPO (Paudyal et al. 1998).

Return on Assets: Return on assets (ROA) is net income divided by total assets. Darmadi and Gunawan (2013) use this measure.

\section{Data and sample}

We sample all 61 private firms and 11 public entities that listed IPOs on the KSE from March 2001 to June 2015. Although numbers for public entities seem small, they mirror the IPO process in a country where privatization is its infancy.

Ours is an event study, so we collected data daily, weekly, and monthly. Sampled firms offered shares to the public via the fixed price method. Data related to the size of private firms, ROA, and ownership structure are from annual reports and prospectuses. Information about issuers, listing dates, offered capital, and subscription ratio is from Capital Issuing Department of the Securities and Exchange Commission of Pakistan. Daily opening-closing stock prices and the KSE-100 index are from the KSE database and other financial websites. We excluded some IPOs from analysis because data were unavailable.

\section{Results and discussion}

\section{Descriptive statistics}

Descriptive statistics of determinants of market-adjusted initial returns and proxies for ownership structure are in Table 1.

Panels A, B and C in Table 1 compare all IPOs. IPOs for private firms, and IPOs for privatized public entities on the KSE from March 2000 to June 2015. Descriptive statistics reveal that arithmetic means and medians are close to each other and positive i.e., data show little variation. Standard deviations cluster near all means. Results for ownership structure indicate that on average 57\% (52\%) of the shares of private firms (privatized entities) are retained by investors owning more than 10,000 shares listed on the KSE. This means that ownership is slightly more concentrated in private than in privatizing IPOs. About $24 \%$ of shares in privatizing IPOs and $31 \%$ in private IPOs are held by owners of large blocks (more than $5 \%$ of the shares). ${ }^{11}$ The (HHI) describing the concentration of ownership among the top five shareholders is $17 \%$ for privatizing IPOs and $18 \%$ for private IPOs, an insignificant difference.

\section{Short-run and long-run performance of private and privatizing IPOs Short-run initial return}

Table 2 compares descriptive statistics of short-run initial raw returns and marketadjusted initial returns for all IPOs, IPOs for privately owned firms, and IPOs for public entities. Initial raw returns are 23.49, 27.32 and $22.79 \%$, respectively. Average marketadjusted initial returns are positive across the board: $23.32 \%$ for the whole sample, $27.65 \%$ for privatization of public entities, and $22.54 \%$ for private IPOs. These returns propose that investors who subscribe to Pakistani IPOs at the issue price and hold their shares through the first day of trading receive considerable gains. Returns for all issues and private IPOs average differ significantly from zero, in line with findings. Results 
Table 1 Descriptive Statistics

\begin{tabular}{|c|c|c|c|c|c|}
\hline \multicolumn{6}{|c|}{ Panel A: All IPOs } \\
\hline$N=72$ & Mean & Median & Maximum & Minimum & Std. Dev. \\
\hline I_Proceed & 5.649 & 5.379 & 9.001 & 2.603 & 1.357 \\
\hline Risk & 0.109 & 0.059 & 0.557 & 0.004 & 0.133 \\
\hline Ret_own & 0.788 & 0.796 & 0.989 & 0.167 & 0.151 \\
\hline Subs & 3.204 & 1.909 & 18.694 & 0.060 & 3.643 \\
\hline M_volt & 0.049 & 0.015 & 1.114 & 0.006 & 0.159 \\
\hline Block & 0.297 & 0.192 & 0.980 & 0 & 0.333 \\
\hline $\mathrm{HHI}$ & 0.180 & 0.125 & 0.646 & 0.004 & 0.165 \\
\hline \multicolumn{6}{|c|}{ Panel B: Privatized Firms } \\
\hline$N=11$ & Mean & Median & Maximum & Minimum & Std. Dev. \\
\hline I_Proceeds & 7.495 & 7.465 & 9.001 & 4.700 & 1.306 \\
\hline Risk & 0.120 & 0.072 & 0.540 & 0.021 & 0.149 \\
\hline Ret_own & 0.865 & 0.900 & 0.989 & 0.619 & 0.116 \\
\hline Subs & 2.690 & 2.337 & 7.450 & 0.130 & 2.126 \\
\hline M_volt & 0.019 & 0.019 & 0.033 & 0.010 & 0.008 \\
\hline Block & 0.242 & 0.112 & 0.886 & 0.000 & 0.317 \\
\hline $\mathrm{HHI}$ & 0.173 & 0.126 & 0.592 & 0.024 & 0.177 \\
\hline \multicolumn{6}{|c|}{ Panel C: Private Firms } \\
\hline$N=61$ & Mean & Median & Maximum & Minimum & Std. Dev. \\
\hline I_Proceeds & 5.317 & 5.165 & 7.830 & 2.603 & 1.076 \\
\hline Risk & 0.108 & 0.059 & 0.557 & 0.004 & 0.132 \\
\hline Ret_own & 0.774 & 0.750 & 0.986 & 0.167 & 0.153 \\
\hline Subs & 3.296 & 1.870 & 18.694 & 0.060 & 3.859 \\
\hline M_volt & 0.054 & 0.014 & 1.114 & 0.006 & 0.172 \\
\hline Block & 0.307 & 0.210 & 0.980 & 0.000 & 0.337 \\
\hline $\mathrm{HHI}$ & 0.182 & 0.124 & 0.646 & 0.004 & 0.164 \\
\hline
\end{tabular}

Table 2 Descriptive Statistics of Initial Returns of Private and Privatizing IPOs

\begin{tabular}{|c|c|c|c|c|c|c|}
\hline & \multicolumn{3}{|c|}{ Initial Raw Return } & \multicolumn{3}{|c|}{ Initial Market adjusted Return } \\
\hline & All & Privatized & Private & All & Privatized & Private \\
\hline Mean ( $p$-value) & $\begin{array}{l}23.485 \\
0.008^{* * *}\end{array}$ & $\begin{array}{l}27.323 \\
0.687\end{array}$ & $\begin{array}{l}22.792 \\
0.033^{* * *}\end{array}$ & $\begin{array}{l}23.320 \\
0.015^{* * *}\end{array}$ & $\begin{array}{l}27.652 \\
0.654\end{array}$ & $\begin{array}{l}22.539 \\
0.048^{* * *}\end{array}$ \\
\hline \multicolumn{3}{|c|}{ Mean Difference between public \& private ( $p$-value) } & $4.53(0.75)$ & & & $5.11(0.72)$ \\
\hline Median & 9.198 & 20.943 & 8.158 & 8.940 & 19.763 & 6.956 \\
\hline Maximum & 144.186 & 75.056 & 144.186 & 142.459 & 74.186 & 142.459 \\
\hline Minimum & -96.496 & -9.531 & -96.496 & -98.101 & -10.107 & -98.101 \\
\hline Std.dev & 43.114 & 26.333 & 45.616 & 43.377 & 27.022 & 45.835 \\
\hline Obs. & 72 & 11 & 61 & 72 & 11 & 61 \\
\hline
\end{tabular}

Note: To test mean difference between private and privatized IPOs initial returns in short run (first trading day) $p$-values are presented in the parenthesis. The ${ }^{* *}$ and ${ }^{* *}$ indicates significance at $1 \%$ and $5 \%$ level respectively 
indicate that privatizing IPOs are more underpriced than private IPOs (Aussenegg, 2000; Rizwan and Khan 2007).

Differences between initial raw returns and market-adjusted means for both categories of IPO are positive (4.53 and 5.11\%, respectively) but not statistically significant. These results neither support asymmetric information theory for initial returns and nor confirm Hypothesis 1 (Aussenegg, 2000).

\section{Aftermarket performance}

Five-year aftermarket performance for all IPOs, private IPOs, and privatizing IPOs appear in Table 3.

The results reported in Table 3 indicate that unlike returns for IPOs, in the short run, five-year aftermarket returns differ among the three samples. For all IPOs, the mean (median) buy-and-hold five-year abnormal return is $-65.54 \%(-72.42 \%)$ and mean values are statistically significant. Wealth relative (WR) is 0.97 , suggesting Pakistani IPOs underperform in the long-run. Negative BHAR values are consistent with Ljungqvist (1996) and Loughran, Ritter and Rydqvist (1994). They argue that overly optimistic investors push market prices up during the first day of trading, but revise their enthusiasm in the long-run, thereby generating underperformance.

Privatizing IPOs generate statistically significant five-year buy-and-hold returns of 80.46\%. This result suggests that governments might pursue market-oriented polices but exert little impact on price behavior. That finding conflicts with Perotti (1995), Jelic and Briston (2003) and Aussenegg (2000).

The mean (median) BHAR value five-year returns of private IPOs is $-91.86 \%$ $(-83.49 \%)$ and statistically significant. Private IPOs in Pakistan underperform in the long-run. These results are mirror evidence of Jelic and Briston (2000) for the Hungarian private sector and Rizwan and Khan (2007) for Pakistan (two-year performance).

With regard to dataset, in measurement of aftermarket long-run BHAR, the number of observed IPOs declines in increasing order. The decay in number of observations is attributable to inadequate duration of trading for newly listed companies (fewer than five years). Data include all available returns for listed companies within five years of an IPO.

The results presented in Table 4 show that the difference in BHAR between private IPOs and privatizing IPOs is negative in the first year and positive for two-to-five years, but differences are insignificant throughout the period. However, BHR in the fifth year is positive and significant, a finding that rejects Hypothesis 3. This evidence accords with findings by Paudyal et al. (1998) for Malaysia and contradicts evidence for Hungary from Jelic and Briston (1999).

\section{Results of regression analysis}

\section{Determinants of short-run underpricing for private and privatizing IPOs}

We regressed one-day market-adjusted initial returns on a dummy of public owned firms interacting with market-adjusted initial returns, market volatility, issue proceeds, firm size, retained ownership, level of company risk, and oversubscription.

Columns 2 and 3 of Table 5 show that the dummy comparing private and privatizing IPOs displays no significant effect on long-term underpricing, indicating that 
Table 3 Aftermarket Performance of IPOs

\begin{tabular}{|c|c|c|c|c|c|c|c|}
\hline \multirow[t]{2}{*}{ Sample } & \multirow[t]{2}{*}{ Period } & \multirow[t]{2}{*}{$N$} & \multicolumn{2}{|l|}{ BHR\% } & \multirow[t]{2}{*}{ WR } & \multicolumn{2}{|l|}{ BHAR\% } \\
\hline & & & Issues & KSE & & Mean & Median \\
\hline \multirow[t]{11}{*}{ All } & 1 week & 72 & $\begin{array}{l}24.92 \\
(0.55)\end{array}$ & $\begin{array}{l}0.428 \\
(0.138)\end{array}$ & 1.34 & $\begin{array}{l}24.49 \\
(0.26)\end{array}$ & 19.98 \\
\hline & 2 weeks & 72 & $\begin{array}{l}23.89 \\
(0.62)\end{array}$ & $\begin{array}{l}1.169 \\
(0.519)\end{array}$ & 1.31 & $\begin{array}{l}22.72 \\
(0.59)\end{array}$ & 18.24 \\
\hline & 1 month & 72 & $\begin{array}{l}23.64 \\
(0.16)\end{array}$ & $\begin{array}{l}2.323 \\
(0.310)\end{array}$ & 1.29 & $\begin{array}{l}21.32 \\
(0.45)\end{array}$ & 9.43 \\
\hline & 2 months & 72 & $\begin{array}{l}21.28 \\
(0.21)\end{array}$ & $\begin{array}{l}2.661^{\mathrm{a}} \\
(0.000)\end{array}$ & 1.25 & $\begin{array}{l}18.62 \\
(0.44)\end{array}$ & 9.26 \\
\hline & 3 months & 72 & $\begin{array}{l}22.19 \\
(0.18)\end{array}$ & $\begin{array}{l}4.26 \\
(0.21)\end{array}$ & 1.24 & $\begin{array}{l}18.68 \\
(0.54)\end{array}$ & 2.73 \\
\hline & 6 months & 71 & $\begin{array}{l}24.46 \\
(0.36)\end{array}$ & $\begin{array}{l}7.25^{c} \\
(0.09)\end{array}$ & 1.22 & $\begin{array}{l}17.879 \\
(0.748)\end{array}$ & -1.427 \\
\hline & 1 year & 66 & $\begin{array}{l}28.556^{a} \\
(0.000)\end{array}$ & $\begin{array}{l}17.540 \\
(0.191)\end{array}$ & 1.13 & $\begin{array}{l}12.760^{a} \\
(0.000)\end{array}$ & -13.531 \\
\hline & 2 year & 65 & $\begin{array}{l}20.905^{a} \\
(0.000)\end{array}$ & $\begin{array}{l}4.024^{c} \\
(0.088)\end{array}$ & 1.24 & $\begin{array}{l}-18.009^{a} \\
(0.000)\end{array}$ & -18.341 \\
\hline & 3 year & 62 & $\begin{array}{l}17.966^{a} \\
(0.000)\end{array}$ & $\begin{array}{l}6.856^{b} \\
(0.048)\end{array}$ & 1.16 & $\begin{array}{l}-42.496^{a} \\
(0.000)\end{array}$ & -48.516 \\
\hline & 4 years & 59 & $\begin{array}{l}8.176^{a} \\
(0.000)\end{array}$ & $\begin{array}{l}16.637 \\
(0.129)\end{array}$ & 0.88 & $\begin{array}{l}-62.740^{a} \\
(0.000)\end{array}$ & -70.182 \\
\hline & Five years & 57 & $\begin{array}{l}36.836^{a} \\
(0.000)\end{array}$ & $\begin{array}{l}38.913^{a} \\
(0.008)\end{array}$ & 0.97 & $\begin{array}{l}-65.539^{a} \\
(0.000)\end{array}$ & -72.421 \\
\hline \multirow[t]{11}{*}{ Privatized } & 1 week & 11 & $\begin{array}{l}24.797 \\
(0.633)\end{array}$ & $\begin{array}{l}-0.179 \\
(0.278)\end{array}$ & 3.30 & $\begin{array}{l}24.977 \\
(0.594)\end{array}$ & 18.004 \\
\hline & 2 week & 11 & $\begin{array}{l}24.541 \\
(0.647)\end{array}$ & $\begin{array}{l}-0.357 \\
(0.822)\end{array}$ & 2.12 & $\begin{array}{l}24.898 \\
(0.570)\end{array}$ & 16.023 \\
\hline & 1 month & 11 & $\begin{array}{l}26.550 \\
0.620)\end{array}$ & $\begin{array}{l}1.663 \\
(0.447)\end{array}$ & 2.97 & $\begin{array}{l}24.886 \\
(0.645)\end{array}$ & 16.605 \\
\hline & 2 months & 11 & $\begin{array}{l}29.929 \\
(0.680)\end{array}$ & $\begin{array}{l}2.517 \\
(0.642)\end{array}$ & 3.02 & $\begin{array}{l}27.411 \\
(0.676)\end{array}$ & 19.390 \\
\hline & 3 months & 11 & $\begin{array}{l}28.986 \\
(0.696)\end{array}$ & $\begin{array}{l}4.272 \\
(0.635)\end{array}$ & 2.61 & $\begin{array}{l}24.713 \\
(0.642)\end{array}$ & 18.252 \\
\hline & 6 months & 11 & $\begin{array}{l}40.367 \\
(0.635)\end{array}$ & $\begin{array}{l}12.274 \\
(0.314)\end{array}$ & 2.20 & $\begin{array}{l}28.093 \\
(0.585)\end{array}$ & 17.574 \\
\hline & 1 year & 10 & $\begin{array}{l}33.951 \\
(0.666)\end{array}$ & $\begin{array}{l}23.260 \\
(0.119)\end{array}$ & 1.32 & $\begin{array}{l}10.690 \\
(0.770)\end{array}$ & -13.051 \\
\hline & 2 year & 9 & $\begin{array}{l}75.634 \\
(0.572)\end{array}$ & $\begin{array}{l}52.449 \\
(0.869)\end{array}$ & 1.37 & $\begin{array}{l}23.184 \\
(0.803)\end{array}$ & 0.000 \\
\hline & 3 year & 9 & $\begin{array}{l}90.391 \\
(0.473)\end{array}$ & $\begin{array}{l}79.439 \\
(0.222)\end{array}$ & 1.21 & $\begin{array}{l}10.951 \\
(0.542)\end{array}$ & -3.771 \\
\hline & 4 years & 9 & $\begin{array}{l}100.841 \\
(0.538)\end{array}$ & $\begin{array}{l}83.529 \\
(0.469)\end{array}$ & 1.18 & $\begin{array}{l}17.310 \\
(0.651)\end{array}$ & -1.998 \\
\hline & Five years & 9 & $\begin{array}{l}130.401 \\
(0.473)\end{array}$ & $\begin{array}{l}49.942 \\
(0.351)\end{array}$ & 2.36 & $\begin{array}{l}80.457 \\
(0.492)\end{array}$ & -5.357 \\
\hline \multirow[t]{4}{*}{ Private } & 1 week & 61 & $\begin{array}{l}24.936 \\
(0.183)\end{array}$ & $\begin{array}{l}0.538^{a} \\
(0.000)\end{array}$ & 1.39 & $\begin{array}{l}24.398 \\
(0.197)\end{array}$ & 20.952 \\
\hline & 2 week & 61 & $\begin{array}{l}23.773 \\
(0.208)\end{array}$ & $\begin{array}{l}1.445 \\
(0.630)\end{array}$ & 1.35 & $\begin{array}{l}22.328 \\
(0.301)\end{array}$ & 18.759 \\
\hline & 1 month & 61 & $\begin{array}{l}23.114 \\
(0.124)\end{array}$ & $\begin{array}{l}2.443 \\
(0.630)\end{array}$ & 1.32 & $\begin{array}{l}20.671 \\
(0.125)\end{array}$ & 7.809 \\
\hline & 2 months & 61 & $\begin{array}{l}20.053 \\
(0.144)\end{array}$ & $\begin{array}{l}2.733^{a} \\
(0.000)\end{array}$ & 1.27 & $\begin{array}{l}17.036 \\
(0.153)\end{array}$ & 8.428 \\
\hline
\end{tabular}


Table 3 Aftermarket Performance of IPOs (Continued)

\begin{tabular}{|c|c|c|c|c|c|c|}
\hline 3 months & 61 & $\begin{array}{l}23.051 \\
(0.248)\end{array}$ & $\begin{array}{l}4.225 \\
(0.624)\end{array}$ & 1.28 & $\begin{array}{l}17.591 \\
(0.265)\end{array}$ & 0.724 \\
\hline 6 months & 60 & $\begin{array}{l}24.05 \\
(0.13)\end{array}$ & $\begin{array}{l}6.58 \\
(0.32)\end{array}$ & 1.26 & $\begin{array}{l}16.04^{a} \\
(0.19)^{2}\end{array}$ & -3.26 \\
\hline 1 year & 56 & $\begin{array}{l}31.91^{\mathrm{a}} \\
(0.00)\end{array}$ & $\begin{array}{l}17.34 \\
(0.21)\end{array}$ & 1.19 & $\begin{array}{l}13.133^{a} \\
(0.00)\end{array}$ & -14.01 \\
\hline 2 year & 56 & $\begin{array}{l}12.70^{a} \\
(0.00)\end{array}$ & $\begin{array}{l}41.98^{c} \\
(0.07)\end{array}$ & 0.70 & $\begin{array}{l}-25.46^{a} \\
(0.00)\end{array}$ & -27.62 \\
\hline 3 year & 53 & $\begin{array}{l}5.87^{a} \\
(0.00)\end{array}$ & $\begin{array}{l}68.23^{b} \\
(0.03)\end{array}$ & 0.49 & $\begin{array}{l}-52.13^{a} \\
(0.00)\end{array}$ & -51.72 \\
\hline 4 years & 50 & $\begin{array}{l}-10.85^{a} \\
(0.00)\end{array}$ & $\begin{array}{l}87.23^{a} \\
(0.00)\end{array}$ & 0.28 & $\begin{array}{l}-77.18^{b} \\
(0.05)\end{array}$ & -77.09 \\
\hline Five years & 48 & $\begin{array}{l}-12.54^{\mathrm{a}} \\
(0.00)\end{array}$ & $\begin{array}{l}106.69^{a} \\
(0.00)\end{array}$ & 0.22 & $\begin{array}{l}91.87^{c} \\
(0.01)\end{array}$ & -83.49 \\
\hline
\end{tabular}

To test whether BHARs of both categories of IPO differ statistically, $p$ values are given in parenthesis. The ${ }^{\mathrm{a}},{ }^{\mathrm{b}},{ }^{\mathrm{c}}$ indicate significance at 1,5 , and $10 \%$, respectively

anomalous underpricing is identical in both categories of IPO. This result contradicts asymmetric information theory. Lee, Taylor, and Waltor (1996), Choi and Nam (1998), and Huang and Levich (1998) confirm this outcome.

There is a positive and significant relation between the risk that indicates ex-ante uncertainty surrounding an IPO and underpricing. This result substantiates Ritter (1984) and Beatty and Ritter (1986) that investors demand higher returns to compensate for fears over future performance.

The positive and significant influence of subscription ratio on first-day marketadjusted returns supports the absorption capacity of the market (Paudyal et al. 1998) and the winner's curse model (Rock 1986). Firm size bears a negative relation to firstday market-adjusted returns. Teker and Ekit (2003), Tian (2011), Megginson and Weiss (1991), and Ibbotson et al. (1994) confirm this finding.

Retained ownership displays no significant relationship with underpricing. This result conflicts with Schindele and Perotti (2001).

There is no significant correspondence between market volatility and initial underpricing, a result is in line with Omran (2005).

Table 4 Mean Differences between Private and Privatizing IPOs in the Long Run

\begin{tabular}{llll}
\hline Period & \multicolumn{2}{l}{ BHR\% } & BHAR\% \\
\cline { 2 - 3 } & Issues & KSE & Mean \\
\hline 1 year & 2.05 & 5.92 & -3.88 \\
& $(0.95)$ & $(0.58)$ & $(0.91)$ \\
2 year & 62.93 & 10.47 & 52.46 \\
& $(0.11)$ & $(0.65)$ & $(0.12)$ \\
3 year & 84.52 & 11.21 & 73.37 \\
& $(0.11)$ & $(0.73)$ & $(0.21)$ \\
4 year & 111.68 & -3.70 & 115.38 \\
& $(0.07)$ & $(0.93)$ & $(0.29)$ \\
5 year & $142.94^{* *}$ & $-56.75^{* *}$ & 199.69 \\
& $(0.04)$ & $(0.04)$ & $(0.35)$ \\
\hline
\end{tabular}

Note: The figures in parenthesis are $p$-values to check the significance of mean diffence. The $* * * * * * *$ indicates the significance at $1 \%, 5 \%$ and $10 \%$ respectively 
Table 5 Determinants of First Day IPOs Underpricing and Aftermarket Long-run IPOs Performance for Public and Private Owned Firms

\begin{tabular}{|c|c|c|c|c|}
\hline & \multicolumn{2}{|c|}{ First Day IPOs Underpricing } & \multicolumn{2}{|c|}{ Long-run IPOs Performance } \\
\hline & \multicolumn{2}{|c|}{$\begin{array}{l}\text { Dependent variable: First day market } \\
\text { adjusted return }\end{array}$} & \multicolumn{2}{|c|}{$\begin{array}{l}\text { Dependent variable: buy and hold abnormal } \\
\text { return over } 5 \text { years }\end{array}$} \\
\hline & Coefficient & t-Statistic & Coefficient & t-Statistic \\
\hline MAR_1 & & & $-1.13^{* * *}$ & -3.19 \\
\hline Pub & 0.08 & 0.63 & 0.82 & 1.27 \\
\hline M_Volt & -0.37 & -1.19 & $0.16^{* * *}$ & 2.81 \\
\hline I_Proceeds & -0.05 & -1.25 & -0.11 & -0.68 \\
\hline F_Size & $-0.04^{* * *}$ & -2.15 & -0.02 & -0.27 \\
\hline Ret_own & -0.24 & -0.76 & $0.19^{* * *}$ & 2.53 \\
\hline Risk & $0.14^{* * *}$ & 2.10 & 0.16 & 1.05 \\
\hline Subs & $0.04^{* * *}$ & 2.04 & 0.06 & 0.84 \\
\hline Constant & $-0.45^{*}$ & -1.78 & -1.28 & -1.18 \\
\hline$R^{2}$ & 0.48 & & 0.28 & \\
\hline F Stat ( $p$ value) & 0.0000 & & 0.0004 & \\
\hline
\end{tabular}

Note: OLS estimation with standard errors adjusted using White's (1980) heteroscedasticity consistent covariance matrix. $* * * * *$, and $*$ indicate significance at 1,5 , and $10 \%$, respectively

Results for issue proceeds show no significant relation to initial underpricing, which is consistent with Setiobudi et al. (2011). Independent variables explain $48 \%$ of the variation, which is reasonable for cross-section regression. The F-test indicates strong model fit with the data.

Determinants of long-run performance i.e., abnormal five-year buy-and-hold returns are reported in the final two columns of Table 5. The relationship between first-day underpricing and long-run performance is negative, significant, and confirmed by Ritter (1991) and Kooli et al. (2006). This result supports the information asymmetry hypothesis that overly optimistic investors misvalue stock prices, thereby earning higher initial returns but prompting long-run underperformance.

Subscription has an insignificant relation to long-run performance. Although higher subscription ratios amplify initial underpricing, they show no significant later association to long-run performance.

Retained ownership has a positive and significant correspondence to long-run performance. Gounopoulos et al. (2012) demonstrate a similar result. This result suggests that governments intent on efficient restructuring retain smaller ownership in privatized public entities, and lessened political influence improves long-run performance.

Firm size and aftermarket risk demonstrate an insignificant correspondence with long-run performance indicating, confirming Omran (2005). Market volatility is related positively and significantly to long-run performance, indicating that higher market volatility is associated with better long-run performance. This finding supports the ex-ante uncertainty hypothesis.

\section{Underpricing and ownership structure of private firms and privatized public entities}

To measure ownership concentration and unbalanced ownership, we use two proxies: Block and HHI. We regressed both against first-day market-adjusted returns and separately against firm characteristics of risk, size, return on assets, subscription. 
Table 6 presents the results of testing the relation between ownership structure and underpricing for both categories of IPOs. The dummy for privatized entities is insignificant, suggesting ownership concentration is similar for both categories of IPOs.

First-day mean market-adjusted returns relate inversely to ownership concentration. These results defy signaling theory, which suggests that concentrated ownership signals issuers' assessments of firm quality and generates underpricing. This result coincides with studies by Michealy and Shaw (1994), Brennan and Franks (1997), and Pham et al. (2003).

Results also reveal that firm size and aftermarket risk relate negatively and significantly in both categories of IPOs, whereas growth (ROA) is positively and significantly ties to ownership concentration only among owners of blocks. Demsetz and Lehn (1985) and Shleifer and Vishny (1997) find significant relationships between firm characteristics and ownership concentration.

Oversubscription correlates positively and significantly with ownership structure. This result confirms Booth and Chua (1996), who argue that a firm's owners seek to retain a desired degree of ownership.

\section{Conclusion and policy implications}

This study has compared IPOs by privately owned firms and IPOs that privatized government entities in Pakistan. It examined their short-and long-run price behavior on the Karachi Stock Exchange from 2001-2015.

Results showed that all Pakistani IPOs during the period were underpriced $23.32 \%$ on their first day of trading, whereas private IPOs were underpriced $22.54 \%$ and privatizing IPOs $27.65 \%$. However, these mean differences are not statistically significant. These similarities suggest that Pakistan's government is committed to privatization and underpriced IPOs for public entities. This result confirms Perotti (1995) and Ausenegg (2000).

For both categories of IPOs, determinants of underpricing are the size of the firm or public entity, aftermarket risk, and subscription ratio. Our findings support the winner's curse model (Rock 1986).

Long-run price behavior of IPOs shows mixed results. Private IPOs outperform for one year and over three-to-five years. BHARs are negative in the long-run for all IPOs and private IPOs. Perhaps overly optimistic investors elevate prices by increasing their initial subscription ratios and later modify their long-run enthusiasm, generating the

Table 6 Effects of Underpricing on Ownership for Private and Privatization IPOs

\begin{tabular}{lccccc}
\hline & \multicolumn{2}{c}{ Dependent Variable: Block } & & \multicolumn{2}{c}{ Dependent Variable: HHI } \\
\cline { 2 - 3 } & Coefficient & t-Statistic & & Coefficient & t-Statistic \\
\hline Pub & 0.06 & 0.65 & & 0.06 & 1.07 \\
F_Size & $-0.04^{* *}$ & -2.46 & & $-0.02^{* *}$ & -2.50 \\
MAR & $-0.14^{* *}$ & -2.40 & & $-0.07^{* * *}$ & -2.69 \\
Risk & $-1.01^{* *}$ & -2.57 & & $-0.46^{* *}$ & -2.18 \\
ROA & $0.06^{*}$ & 1.80 & & 0.02 & 1.14 \\
Subs & $0.02^{* *}$ & 1.84 & & $0.05^{* *}$ & 1.91 \\
Constant & $1.08^{*}$ & 3.11 & & $0.64^{* * *}$ & 3.28 \\
R & 0.25 & & 0.27 & \\
F Stat $(p$ value $)$ & 0.04 & & 0.04 & \\
\hline
\end{tabular}

Note: OLS estimation with standard errors adjusted using White's (1980) heteroscedasticity consistent covariance matrix. The ${ }^{* * *}, *^{*}$, and * indicate significance at $1 \%, 5 \%$, and $10 \%$, respectively based on t-test 
underperformance noted by Ljungqvist (1996), Loughran, Ritter and Rydqvist (1994). Among public IPOs, BHAR outperforms in the short-run and up to five years, a finding consistent with Perotti (1995). However, the positive mean difference in long-run for privatized and private IPOs is statistically insignificant. This evidence for Pakistan accords with findings by Paudyal et al. (1998) for Malaysia but contradicts evidence from Jelic and Briston (1999) for Hungary.

Determinants of five-year aftermarket returns for private and privatizing IPOs include first-day market-adjusted abnormal returns, market volatility, and proportion of shares owned. Findings for first-day market-adjusted return support the information asymmetry hypothesis overly optimistic investors bid up prices, generating higher initial returns, and prices decline as they moderate their enthusiasm, resulting in subsequent underperformance (Ritter 1991; Kooli et al. 2006).

Results for ownership concentration are similar for both categories of IPOs, a finding that contravenes signaling theory. First-day market-adjusted initial returns have negative and significant correspondence to ownership concentration. Firm/entity size and aftermarket risk correlate negatively, whereas firm/entity growth and oversubscription correlate positively with concentration. These results support those in Michealy and Shaw (1994), Demsetz and Lehn (1985), Shleifer and Vishny (1997), and Booth and Chua (1996).

On the bases of above stated results, the study proposes some implications. Regulatory authorities such as Securities and Exchabge Commission of Pakistan (SECP) are required to take some steps to minimize concentration in ownership structure of new issues. This will make dispersion in ownership structure and to involve more small investors which are mostly uninform of IPOs prices. As underpricing is indirect cost of any issue for the firm, so issuer/regulators must set a specific range of underpricing to achieve its objective of dispersed ownership. The awareness increase the participation of more investors that will enhance performance of new issues.

\section{Endnotes}

${ }^{1}$ Evidence for a significantly positive long-run performance of public IPOs is also provided by Choi et al. (2000) and Dewenter and Malatesta (2000).

${ }^{2}$ KSE was established on September 18, 1948.

${ }^{3}$ Political considerations might dictate lower retention ratios to preserve the credibility of transferring control to the private sector. A government committed to privatization will underprice its IPO, producing a negative relationship between price and the fraction of ownership offered by an IPO.

${ }^{4}$ Setiobudi et al. (2011) and Omran (2005) use OLS to estimate IPO performance models.

${ }^{5}$ Subscription ratio is the number of IPO shares buyers wish to purchase divided by the number offered while retained ownership is the number of shares retained by the issuer as a percentage of total shares issued. In short, Subscription ratio is attained by investor behavior and retained ownership is linked with issuer.

${ }^{6}$ MAR measures short-term, first-trading-day, average market-adjusted abnormal returns. Buy-and-hold abnormal returns are used to measure an IPO's long-run performance. This method uses the product of all previous raw returns.

${ }^{7}$ Returns are adjusted for dividends. 
${ }^{8}$ See Keloharju (1993) for the IPO market in Finland, Kunz and Aggarwal (1994) for Switzerland, or Paudayal (1998) for Malaysia.

${ }^{9}$ Ausenegg (2000) and Boissin and Sentis (2012) use a similar formula.

${ }^{10}$ Wealth relative (WR) is a term and used as a performance indicator of an IPOs.

${ }^{11}$ See Pham et al. (2003), where 43\% of shares are held by block -holders in 113 private IPOs.

Acknowledgement

Malik Muhammad Shehryar MPhil Economics and Finance from PIDE is consulted for data analysis.

Funding

There are no funding sources.

Authors' contributions

HM collected the data, write the first draft. AYJ design the research study, do the statistical analysis and write the final draft. While doing estimation and statistical analysis both author consulted MMS. Both authors read and approved the final manuscript.

\section{Competing interests}

The authors declared that they have no competing interests.

\section{Author details}

${ }^{1}$ Economics Department, Pakistan Institute of Development Economics (PIDE), Quaid-i-Azam University, P.O. Box 1091, Islamabad, Pakistan. ${ }^{2}$ Pakistan Institute of Development Economics (PIDE), Economics and Finance Department, Quaid-i-Azam University, P.O. Box 1091, Islamabad, Pakistan.

Received: 1 May 2016 Accepted: 10 November 2016

Published online: 28 November 2016

\section{References}

Aggarwal R, Leal R, Hernandez L (1993) The aftermarket performance of initial public offerings in Latin America. Finan Manag 2:42-53

Aggarwal R, Rivoli P (1990) Fads in the initial public offering market? Financial Management. 19:45-57.

Al-Hassan A, Delgado F, Omran M (2010) The under-pricing of IPOs in the gulf cooperation council countries. R in Int Busand Finan 24:344-360

Allen F, Faulhaber G (1989) Signaling by underpricing in the IPO market. J Finan Econ 23:303-323

Aussenegg W (2000). Privatization versus private Sector Initial Public Offerings in Poland. Multinational Finan J. 4: 69-99.

Barber BM, Lyon JD (1997) Detecting long-run abnormal stock returns: the empiricalpower and specification of test statistics. J Finan Econ 43:341-372

Barnes E, Walker M (2006) The seasoned-equity issues of UK firms: market reaction and issuance method choice. J Bus Finan Acc 33:45-78

Beatty RP, Ritter JR (1986) Investment banking, reputation, and the underpricing of initial public offerings. J Finan Econ 15:213-232

Booth JR, Chua L (1996) Ownership dispersion, costly information, and IPO underpricing. J Finan Econ 41:291-310

Boycko M, Shleifer A, Vishny RW (1996) A theory of privatization. Econ J 106:309-319

Breda ER, Collis BD, and Psevdos N (1997) Bargain buys, why australian government IPOs are not as cheap as some. JASSA 17-23.

Brennan MJ, Franks J (1997) Underpricing, ownership and control in initial public offerings of equity securities in the UK. J Finan Econ 45:391-413

Cai X, Liu GS, Mase B (2008) The long-run performance of initial public offerings and its determinants: the case of China. Quant Finan Acc Rev 30:419-432

Carter R, Manaster S (1990) Initial public offerings and underwriter reputation. J Finan 45:1045-1068

Cheema A. Bari F. and Saddique O. (2003) Corporate governance in Pakistan: ownership, control and the law. Lahore University of Management Sciences, Lahore

Chen S, Bangassa K, Brookfield D (2011) Long-Run Performance of Chinese Initial Public Offerings: Further Evidence. Asia-Pacific Journal of Financial Studies. 40:285-316.

Chen J, \& Strange R (2004) The Effect of ownership structure on the underpricing of initial public offering: evidence from Chinese stockmarkets. The Management Centre Research Papers.

Choi S. \&Nam S. (1998) The short run performance of IPOs of privately and publicly owned firms: International evidence. Multinational Finance Journal 3:225-244.

Darmadi S, Gunawan R (2013) Underpricing, board structure and ownership: an empirical examination of Indonesian IPO firms. Manag Finan 39:181-200

Demsetz H. \& Lehn K. (1985) The structure of corporate ownership: causes and consequences. J Polil Econ. 93:1155-1177.

Dewenter K. \& Malatesta P. (1997) Public offerings of state-Owned and privately owned enterprises: An international comparison, J Finan 52:1659-1679.

Gounopoulos D. Nounis C. \& Thomadakis S. (2012) Long-term Performance of Greek IPOs. Eur Financ Manag 18:117-141. 
Grinblatt M, Hwang CY (1989) Signalling and the pricing of new issues. J Finan. 44:393-420.

Habib MA. \& Ljungqvist AP. (2001) Underpricing and entrepreneurial wealth losses in IPOs: Theory and evidence. ev Financ Stud. 14:433-458.

Huang Q, Levich R (1998) Underpricing of new equity offerings by privatized firms: an international test. Int J Theor Appl Financ 6:1-30

Ibbotson RG (1975) Price performance of common stock new issues. J Finan Econ 2:235-72

Ibbotson R, Sindelar J, Ritter J (1988) Initial public offerings. J Appl Corp Financ 1:37-45

Ibbotson R, Sindler J, Ritter J (1994) The market's problem with the pricingof initial public offerings. J Appl Corp Financ 7:66-74

Ikoku AE (1998) Influence-seeking and the pricing of initial public offerings and privatizations: evidence from the nigerian equity market. Working paper of University of southern California

Jacquillat B (1987) Nationalization and privatization in contemporary France. Gov Union Rev 8:21-50

Jelic R, Briston R (1999). Hungarian privatization strategy and financial performance of privatized companies. J of Bus Finan \& Acc 26:1319-1357.

Jelic R, Briston R (2000) Privatization initial public offerings: the polish experience. Working paper. University of Birmingham, Birmingham.

Jelic R, Briston R (2003) Privatization initial public offerings: The Polish experience. European Financial Management, 9:457-484. Jenkinson T, Mayer C (1988) The privatization process in France and UK. Eur Econ Rev 32:482-490

Keloharju M (1993) The winner's curse, legal liability, and the long-run performance of initial public offerings in Finland. J Finan Econ 34:251-277

Koh F, Walter T (1989) A direct test of rock's model of the pricing of unseasoned issues. J Finan Econ 23:251-272

Kooli M, Suret JM (2004) The aftermarket performance of initial publicofferings in Canada. J Multinational Finan Manag 14:47-66

Kooli M, L'Her JF, Suret JM (2006) Do IPOs really underperform in the long-run? New evidence from the Canadian market. J Private Equity 9:48-58

La Porta, R. Lopez-de-Silanes, F. and Shleifer, A. (1999). Corporate ownership around the world. J of Finan 54:471-517

Leech D, Leahy J (1991) Ownership structure, control type classifications and the performance of large British companies. The Economic Journal 101:1418-1437.

Lemmon ML, Lins KV (2003) Ownership structure, corporate governance, andfirm value: evidence from the East Asian financial crisis. J Finan 58:1445-1468

Levis M (1993) The long run performance of initial public offerings. The UKexperience 1980-1988. Finan Manag 22:28-41

Ljungqvist AP (1996) Can firms outwit the market? Timing ability and the long-run performance of IPOs, in: Levis, M. (Hrsg.), Empirical issues in raising equity capital, Elsevier, Am sterdam 1996, 215-244.

Loughran T, Ritter J (1995) The new issues puzzle. J Finan 50:23-51

Loughran T, Ritter JR (2000) Uniformly least powerful tests of marketefficiency. J Finan Econ 55:361-389

Loughran T, Ritter JR, Rydqvist (1994) Initial Public Offerings: International Insights, Pacific-Basin Finance Journal, 2:165-99.

Lyon JD, Barber BM, Tsai CL (1999) Improved methods for tests of long-run abnormal stock returns. J Finan 54:165-201

Menyah K, Paudyal K (1996) Share issue privatizations: the UK experience. In: Levis M (ed) Empirical Issues in Raising Equity Capital: AdvanceinFinance, Investment and Banking. Elsevier, Amsterdam

Michaely R, Shaw WH (1994) The pricing of initial public offerings: Tests of adverse-selection and signalling theories. Review of Financial Studies 7:279-319.

Miller MH (1977) Debt and taxes. J Finan 32:261-75

Miller RE, Reilly FK (1987) An examination of mispricing, returns and uncertainty for initial public offerings. Finan Managt 16:33-38

Paudyal K, Saadouni B, Briston RJ (1998) Privatization initial public offerings inMalaysia: initial premium and long-term performance. Pac Basin Financ J 6:427-451

Perotti EC, Guney SE (1993) The structure of privatization plans. FinanManag 22:84-98

Perotti EC (1995) Credible Privatization. The Amer Econ Rev 85:847-859.

Pham et al (2003) Underpricing, stock allocation, ownership structure and post-listing liquidity of newly listed firms, J of Bank and Finan, 27:919-947.

Ritter J (1984) Thehotissue'market of 1980. J of Bus 57:215-240

Ritter J (1991) The long-run performance of initial public offerings. J Finan 46:3-27

Rizwan M, Khan S (2007) Long-run performance of privatization versus private sector industrial IPOs in Pakistan. J Finan Econ 15:93-95

Rock K (1986) Why new issues are underpriced. J Finan Econ 46:3-27

Setiobudi M, Warganegara DL, Warganegara DS (2011) Empiricalinvestigation of the underpricing phenomenon on IPOs in privatization of SOES: evidence from Indonesia. J Applied Finan Acc 3:109-135

Shehryar MM, Javid AY (2014) Liquidity benefits from underpricing: Evidence from Initial Public Offerings Listed at Karachi Stock Exchange. PIDE Working Paper 101. Pakistan Institute of Development Economics, Islamabad, Pakistan.

Shleifer A, Vishny R (1997) A survey of corporate governance. J Finan 52:737-775

Stoughton NM, Zechner J (1998) IPO-mechanisms, monitoring and ownershipstructure. J Finan Econ 49:45-77

Suchard JA, Singh M (2007) Determinants of the Pricing of Privatization IPOs in the UK and Australia. Intl J Buss, 12:361-384.

Teker S, Ekit Ö (2003) The performance of IPOs in Istanbul stock exchangein year 200\|ll. DogusÜniversitesiDergisi 4:117-128

Tinic S (1988) Anatomy of initial public offerings of common stock. J Finan 43:789-822

Venkatesh S, Neupane S (2005) Does ownership structure effect IPOs underpricing: evidence from Thai IPOs. Corp Ownersh Control 3:2005-2006

Vickers J, Yarrow G (1988) Privatization: an economic analysis. The MIT Press, London

Vieira C, Serra AP (2006) Abnormal returns in privatization public offerings: the case of Portuguese firms.

NotasEconómicas 22:22-135

Welch I (1989) Seasoned offerings, imitation costs and the underpricing of initial public offerings. J Finan 44:421-449. 